\title{
SCANNING NEAR-FIELD OPTICAL MICROSCOPY OF LIVE CELLS IN LIQUID
}

\author{
R. Januškevičius ${ }^{\mathrm{a}}$, V. Vaičikauskas ${ }^{\mathrm{a}}$, D.J. Arndt-Jovin ${ }^{\mathrm{b}}$, and T.M. Jovin ${ }^{\mathrm{b}}$ \\ ${ }^{a}$ Department of Nonlinear Optics and Spectroscopy, Institute of Physics, Savanoriu 231, LT-02300 Vilnius, Lithuania \\ ${ }^{\mathrm{b}}$ Department of Molecular Biology, Max Planck Institute for Biophysical Chemistry, Am Fassberg 11, D-37077 Göttingen, \\ Germany
}

Received 14 March 2005

\begin{abstract}
A scanning near-field optical microscope (SNOM) is applied to fluorescence imaging of biological samples in liquid, including live cells. The SNOM is mounted on a Zeiss Axiovert $135 \mathrm{TV}$ fluorescence microscope. For feedback we use tuning fork shear force method. The scanning tip is produced from a $125 \mu \mathrm{m}$ optical fibre ( $8.3 \mu \mathrm{m}$ core diameter) in a commercial Sutter P-2000 pipette puller and is coated with aluminium. Other commercial tips have also been used. Coarse $z$-axis adjustment is hydraulic, and fine positioning is accomplished with piezoelectric tube units. We have constructed the original liquid chamber, which allows long term stability of scanning and highest values of the $\mathrm{Q}$ factor (300 or more). The depth of liquid layer was less than $40 \mu \mathrm{m}$. Near-field images - the topography and distribution of membrane fluorescence of live human epithelial A431 cells, stably transfected with an EGFP fusion protein of the epidermal growth factor transmembrane receptor protein (EGFR, erbB1), were obtained in liquid.
\end{abstract}

Keywords: scanning near-field optical microscopy, fluorescence microscopy, sub-diffraction limit, live cells

PACS: 07.79.Fc, 87.64.Xx

\section{Introduction}

Fluorescence microscopy is a powerful experimental tool for visualisation of biological specimens and the determination of the distribution of fluorescently labelled objects within the sample. Scanning near-field optical microscopy (SNOM) can simultaneously map topographic and optical properties (fluorescence, absorption) on and of the surfaces. The spatial resolution of traditional optical microscopy with conventional farfield optics is limited by diffraction to approximately $\lambda / 2$. This limit does not apply to near-field microscopy, in which a miniature optical probe is scanned over a sample surface at nanometre distances. In this case the resolution is defined mainly by the physical size of the aperture.

SNOM is a highly useful tool for investigating the long-range lateral distribution of labelled objects in the $100-1000 \mathrm{~nm}$ range and has been used to probe various biological molecules and systems, such as green fluorescent protein (GFP) in bacteria [1], cells labelled with fluorescent anti-erbB2 monoclonal antibodies [2], and fluorescently labelled plasma membranes of fixed human skin fibroblasts [3]. Data collected from dry biological samples may exhibit artefacts caused by drying of the samples [3]. Furthermore, imaging by SNOM has been performed primarily on fixed cells $[4,5]$.

Several feedback mechanisms have been proposed for imaging samples under water $[6,7]$. The best resolution reported to date for SNOM operated in liquid on hard samples is $60 \mathrm{~nm}$ [8]. A shear-force non optical "tuning fork" type distance control method is known to have a very large quality factor Q [9] and is very effective in the SNOM systems operating in air. Unfortunately, the quality factor sharply decreases upon immersion of the fibre tip into water. The liquid depth must be minimized $(50-100 \mu \mathrm{m})$ in order to reduce the damping of tip oscillation and the consequent loss in the $\mathrm{Q}$ factor of resonance caused by the drag force of the liquid $[5,10]$. The vibrational mode of tuning fork is conserved upon full immersion in water [11]. Hydrophobic tips were proposed by Sommer and Franke [12].

For application of this microscopy technique to the investigation of soft samples, such as living cells in liquid, entirely new requirements emerge. This concerns the adjustment of distance between the tip and the sample. In water, a very precise control of the gap between the tip and the object is essential to prevent catastrophic tip-sample collision. Living cells have a significant 
thickness (typically $\sim 10 \mu \mathrm{m}$ ) and need to be imaged in an aqueous environment. For these reasons there is very scarce experimental research with live cels [14] with high spatial resolution. Only $200-300 \mathrm{~nm}$ resolution was achieved using the ion conductance as a distance control mechanism [13]. Using a diving bell concept an $80 \mathrm{~nm}$ resolution was achieved with the Q factor $200[14,15]$. However, the increase of the $Q$ factor and as a consequence the scanning speed remain the main problems in the live cell microscopy.

There is a second factor necessitating a modification of the tip construction for experiments in water: due to the similarity of refractive indexes of water and the quartz core, the total internal reflection is frustrated and the light does not reach the tip. Very high refraction index fibre tips should be used, or the tip of the waveguide should be coated with metal.

Here we present the key features of the high Q factor microscope as well as the original results of topographic and fluorescence views of live cells. Our results are promising with respect to the maintenance of a stable and very shallow cell (only 20-40 $\mu$ m layer of water) for further development of SNOM.

\section{Materials and methods}

The SNOM is mounted on a Zeiss Axiovert 135 TV fluorescence microscope. To ensure the recognition of the object of interest with a high optical resolution (Fig. 1(a,b)), we operate in the illumination mode using shear force for feedback control.

We use a commercially available controller and software (RHK SPM 100 with control module V-SCAN 100). The scanning tip is produced from a $125 \mu \mathrm{m}$ optical fibre (Siecor, $8.3 \mu \mathrm{m}$ core diameter) by a heating and pulling sequence in a commercial Sutter P-2000 pipette puller and is coated sequentially with $30 \mathrm{~nm} \mathrm{Cr}$ and $120 \mathrm{~nm} \mathrm{Al} \mathrm{films.} \mathrm{A} \mathrm{coated} \mathrm{fibre} \mathrm{tip} \mathrm{prevents} \mathrm{light}$ from exiting into the liquid before reaching the end of the probe. The tip cone angle is kept relatively small $\left(\sim 20^{\circ}\right)$. Commercially available tips (Nanonics, Shearforce NSOM Fiber Probe 488, $\phi 50$ and $100 \mathrm{~nm}$ ) have also been used.

The fibre tip is glued to the tuning fork with cyanacrylate. In order to simplify this process, the fibre tip and the tuning fork are first fixed on the scanning head and then glued together; a piezoelectric plate is also attached $\left(1 \mathrm{~mm}\right.$ thickness, $5 \times 5 \mathrm{~mm}^{2}$ area, material PIC151, $d_{33}=450 \mathrm{pm} \mathrm{V}^{-1}$, Physik Instrumente, Germany) (Fig. 1(c)). The scanning head has manual coarse $x y$-position adjustment and a coarse hydraulic

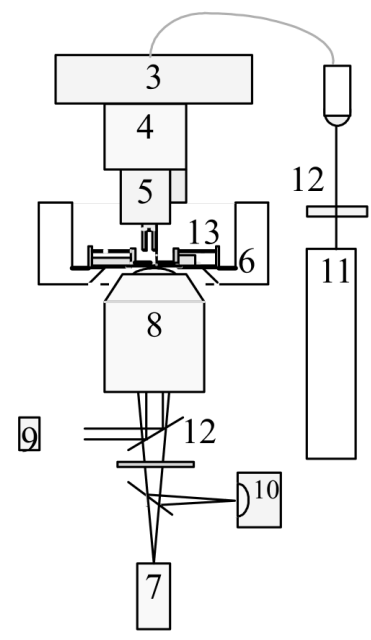

(a)

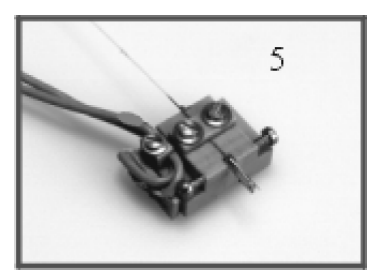

(c)

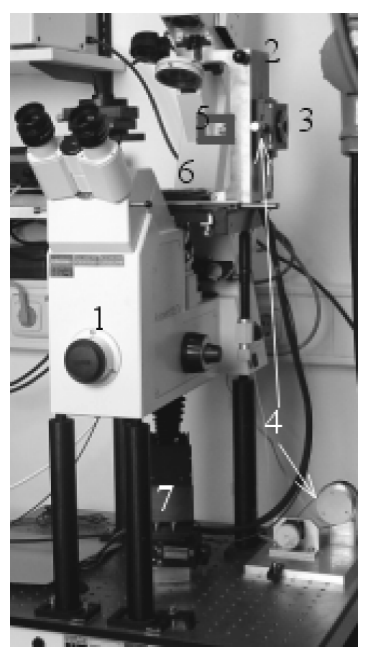

(b)

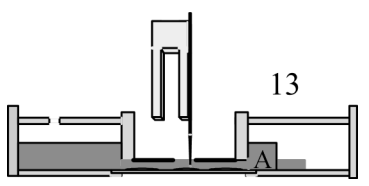

(d)
Fig. 1. SNOM designed for imaging of live cells. (a) Schematic diagram and (b) photo view of microscope. 1 is Zeiss Axiovert 135 TV fluorescence microscope, 2 is uncovered holder, 3 is coarse $x y$ position adjustment with microstage, 4 is hydraulic approach unit, 5 is holder of fibre and of tuning fork, 6 is nanostage used for XYZ scanning, 7 is photodiode, 8 is objective, 9 is a $\mathrm{Hg}$ lamp, 10 is eye piece, 11 is laser, 12 is filter, 13 is liquid chamber. (c) Schematic diagram: holder of fibre and of tuning fork. (d) Schematic diagram of liquid chamber.

approach unit in the $z$ direction. Due to the use of a hydraulic approach, the microscope is relatively impervious to mechanical and acoustic noise.

The piezo plate is driven by a signal from a generator incorporated into a lock-in amplifier (Stanford Research model 830). The signal from the tuning fork (Bürklin, quartz $32768 \mathrm{~Hz}$ ) is pre-amplified (Princeton Applied Research model 5113) and detected with the lock-in amplifier, the output of which is used as the feedback signal to the RHK controller. An offset applied to this signal defines the set-point of the feedback loop and thereby the working distance between tip and sample. The PI nanostage ( $x-y$ scanning) and piezoelectric tube ( $z$ scanning) is driven from the RHK controller through a PI driver (Physik Instrumente, module E-863.10). Scanning data (fluorescence) are collected with the same RHK controller.

For imaging, the $488 \mathrm{~nm}$ line of an $\mathrm{Ar}^{+}-\mathrm{Kr}^{+}$mixed gas laser (Performa, Spectra Physics, Mountain View, CA) was stabilized by a laser intensity stabilizer (Cam- 


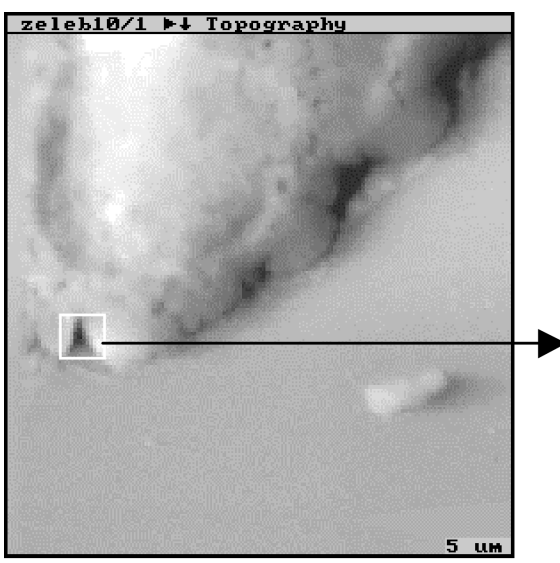

(a)

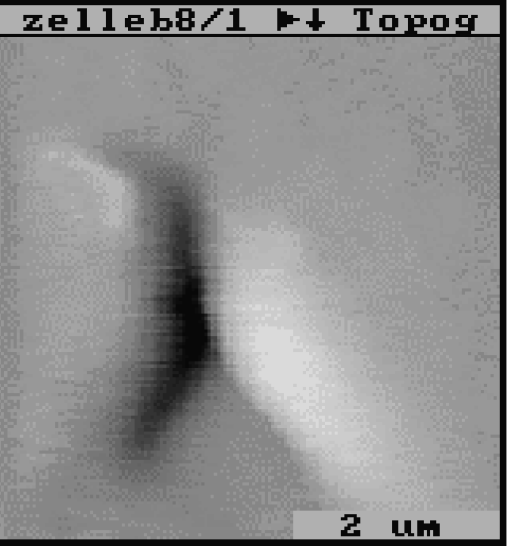

(b)

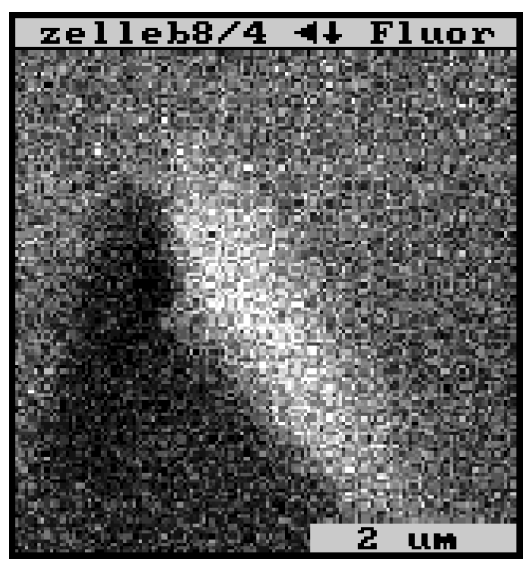

(c)

Fig. 2. Live human A431 cells (A4 erbB2 Y13). (a, b) Topographic image, (c) fluorescence image.

bridge Research \& Instrumentation, Woburn, MA) and coupled into the fibre. In the experiments reported here, the fluorescence was selected by a bandpass filter $(505 \mathrm{~nm})$ and detected with a single-photon counting avalanche photodiode (SOCM-AQR-13, EG\&G Optoelectronics, Vaudreuil, Quebec, Canada). Measurements were performed at room temperature under ambient conditions.

\subsection{Liquid chamber}

To operate the SNOM in liquid, we designed a chamber for a $20-40 \mu \mathrm{m}$ layer of liquid (Fig. 1(d)). The chamber consists of two separate parts, the bottom part of which is a cap with a central hole to accommodate $18 \mathrm{~mm}$ diameter glass cover slips. The top part (cover) has a central $2 \mathrm{~mm}$ diameter hole. The evaporation liquid is compensated by replenishment through a capillary tube from chamber A. The distance between the glass cover slip and the top hole in the cover determines the depth of liquid. This liquid chamber con-

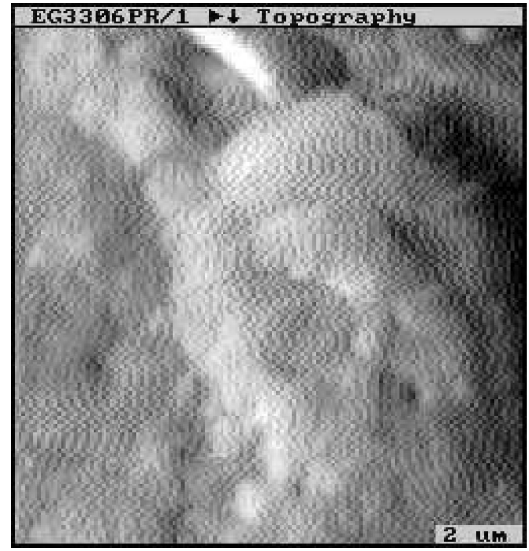

(a) struction permits scanning in an aqueous environment for $\sim 3$ hours without refilling of liquid.

\section{Results and discussion}

The simultaneously scanned topographic and fluorescence images of live human A431 cells (A4 erbB2 Y13) are shown in Fig. 2. The scan area is $40 \times 40 \mu \mathrm{m}^{2}$ (Fig. 2(a)) and $5 \times 5 \mu \mathrm{m}^{2}$ (Fig. 2(b, c)). The height of the cell in the scanned area is $4.8 \mu \mathrm{m}$. Live human A431 cells transfected with EGFP-EGF fusion protein (EG33) in liquid are shown in Fig. 3. An area of $128 \times 128$ pixels was scanned with an integration time of $3 \mathrm{~ms} /$ pixel for fluorescence light. The image of the cell was scanned in an aqueous salt solution. Bright regions in the fluorescence image correspond to areas with high fluorescence and a high concentration of the EGFP-EGF fusion protein. Previous SNOM studies demonstrated that a related receptor (erbB2) is clustered into small domains on cell surfaces [2].

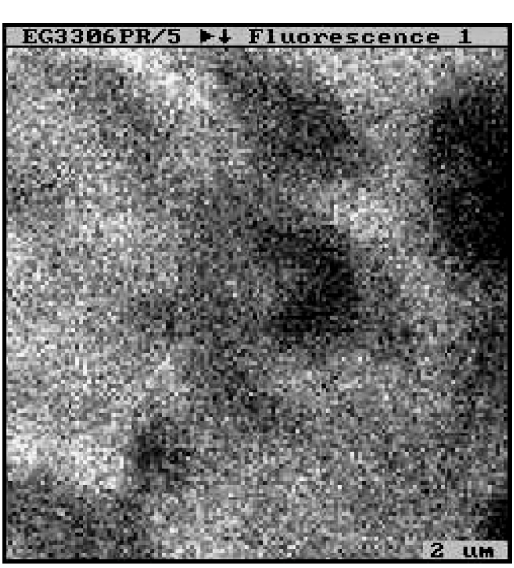

(b)

Fig. 3. Live human A431 cells transfected with EGFP-EGF fusion protein (EG33) in liquid. (a) Topographic image, (b) fluorescence image. 
Scanning was accomplished with a small cone angle tip to minimize the water drag force. The tip was immersed $\sim 40 \mu \mathrm{m}$ into the liquid in our setup. In this case the quality factor Q decreased only by about 5-7\% (compared to air) which is much better when compared to that obtained in [15]. This kind of tip exhibits a low interaction force with the cell, thus reducing damage to the latter. Using this concept we routinely obtain Q factors of 300 or higher.

Obtaining an intense fluorescence signal in illumination mode requires the operation at a lower light intensity in comparison to a SNOM in which the tip performs both the illumination and the detection functions.

There are, however, potential hazards for cell damage during operation, e. g., fast scan speed and/or in the event of unsuccessful approach of the tip to the sample. We used a scan speed of $10 \mu \mathrm{m} / \mathrm{s}$ and a fast feedback control (low integration time). For cells exhibiting substantial motion, this scanning speed did not suffice for the acquisition of full images. However, several scans of the same part of the cell were often possible before the quality of the topographic view declined. To minimize damage to the cell, we performed the approach of the tip in two steps: first to the sample outside the cell, and then to the cell itself.

Because the cells have a significant thickness, the excitation light propagating to the far-field would illuminate distant fluorophores, causing a relatively high background fluorescence signal upon which the nearfield signal is superimposed [16]. To compensate for this effect, certain further design modifications are required.

\section{Conclusions}

In this work we have demonstrated the subdiffraction resolution on the membrane of live cells using SNOM. The original construction of the liquid chamber allows for the long term stability of scanning and the highest values of the $\mathrm{Q}$ factor (300 or more). In the scan area the liquid layer is shallow $(20-40 \mu \mathrm{m})$. Using such a cell the images of soft human epithelial A431 cells in liquid with the $120 \mathrm{~nm}$ spatial resolution have been obtained. The obtained high values of the $\mathrm{Q}$ factor enable multiple scans of the same cell and prevent the cell damage. Our results are promising in further investigation of the distribution of fluorescently labelled objects on the surface of live cells.

\section{References}

[1] V. Subramaniam, A.K. Kirsch, and T.M. Jovin, Cell biological applications of scanning near-field optical microscopy (SNOM), Cell. Mol. Biol. 44, 689-700 (1998).

[2] P. Nagy, A. Jenei, A.K. Kirsch, J. Szöllösi, S. Damjanovich, and T.M. Jovin, Activation dependent clustering of the erbB2 receptor tyrosine kinase detected by scanning near-field optical microscopy, J. Cell Sci. 112, 1733-1741 (1999).

[3] J. Hwang, L.A. Gheber, L. Margolis, and M. Edidin, Domains in cell plasma membranes investigated by near-field scanning optical microscopy, Biophys. J. 74, 2184-2190 (1998).

[4] H. Muramatsu, N. Chiba, K. Homma, and K. Nakajima, Near-field optical microscopy in liquids, Appl. Phys. Lett. 66, 3245-3247 (1995).

[5] L.A. Gheber, J. Hwang, and M. Edidin, Design and optimization of a near-field scanning optical microscope for imaging biological samples in liquid, Appl. Opt. 37, 3574-3581 (1998).

[6] P.J. Moyer and S.B. Kämmer, High-resolution imaging using near-field scanning optical microscopy and shear force feedback in water, Appl. Phys. Lett. 68, 33803382 (1996).

[7] T.H. Keller, T. Rayment, D. Klenerman, and R.J. Stephenson, Scanning near-field microscopy in reflection mode imaging in liquid, Rev. Sci. Instrum. 68, 1448-1454 (1997).

[8] T.H. Keller, T. Rayment, and D. Klenerman, Optical chemical imaging of tobacco mosaic virus in solution at 60-nm resolution, Biophys. J. 73, 653-658 (1998).

[9] A. Karrai and R. Grober, Piezo-electric tuning fork tipsample distance control for near field optical microscopes, Ultramicroscopy 61, 197-205 (1995).

[10] P. Lambelet, M. Pfeffer, A. Sayah, and F. MarquisWeible, Reduction of tip-sample interaction forces for scanning near-field optical microscopy in a liquid environment, Ultramicroscopy 71, 117-121 (1998).

[11] W.H. Rensen and N.F. Hulst, Imaging soft samples in liquid with tuning fork based shear force microscopy, Appl. Phys. Lett. 77, 1557-1559 (2000).

[12] A.P. Sommer and R.P. Franke, Hydrophobic optical elements for near-field optical analysis (NOA) in liquid environment - a preliminary study, Micron 33, 227231 (2002).

[13] A.H. Mannelquist, H.I. Iwamoto, G. Szabo, and Z. Shao, Near-field optical microscopy in aqueous solution: Implementation and characterization of a vibrating probe, J. Microsc. 205, 53-60 (2002).

[14] M. Koopman, A. Cambi, B.I. de Bakker, B. Joosten, C. Figdor, N.F. van Hulst, and M. Garcia-Parajo, Nearfield scanning optical microscopy in liquid for high resolution single molecule detection on dentritic cells, FEBS Lett. 573, 6-10 (2004). 
[15] M. Koopman, B.I. de Bakker, M. Garcia-Parajo, and N.F. van Hulst, Shear force imaging of soft samples in liquid using a diving bell concept, Appl. Phys. Lett. 83, 5083-5085 (2003).
[16] R.T. Doyle, M.J. Szulzcewski, and P.G. Haydon, Extraction of near-field fluorescence from composite signals to provide high resolution images of glial cells, Biophys. J. 80, 2477-2482 (2001).

\title{
GYVU LA¿STELIU SKENUOJANTI ARTIMO LAUKO MIKROSKOPIJA SKYSTYJE
}

\author{
R. Januškevičius a, V. Vaičikauskas ${ }^{\text {a }}$, D.J. Arndt-Jovin ${ }^{\text {b }}$, T.M. Jovin ${ }^{\text {b }}$ \\ ${ }^{a}$ Fizikos institutas, Vilnius, Lietuva \\ ${ }^{\mathrm{b}}$ Makso Planko Biofizinès chemijos institutas, Gétingenas, Vokietija
}

\section{Santrauka}

Sukurtas ir sukonstruotas optinis artimo lauko mikroskopas pritaikytas gyvų ląstelių ir kitų biologinių objektų, esančiu tirpaluose, fluorescenciniam signalui fiksuoti. Mikroskopas sumontuotas ant fluorescencinio Zeiss Axiovert 135 mikroskopo. Skenavimui naudotos adatos, pagaminamos kaitinant ir tempiant šviesolaidi, kurios vèliau metalizuojamos. Sukonstruota speciali skystinè kiu- veté, pritaikyta biologiniams objektams skenuoti tirpale. Mažas tirpalo gylis kiuveteje minimaliai itakoja adatos jautri skenuojant bandinio paviršiu ir nekritiškai sumažina adatos rezonanso $Q$ faktorių. Tai leidžia skenuoti lengvai pažeidžiamą gyvų ląstelių paviršių. Gauti eksperimentiniai gyvų žmogaus epitelio A431 ląstelių, žymetų EGFP baltymu, artimo lauko fluorescencijos ir topografijos vaizdai. 